\title{
6. PICRITIC BASALTS FROM THE SIQUEIROS TRANSFORM FAULT
}

\author{
Ed L. Schrader, Department of Geology, Duke University, Durham, North Carolina ${ }^{1}$ \\ B. R. Rosendahl and William J. Furbish, Department of Geology, Duke University, Durham, North Carolina \\ and \\ George Meadows, Department of Geology, Emory University, Atlanta, Georgia
}

\begin{abstract}
Fresh, glassy picritic basalts have been recovered in a dredge haul in the Siqueiros transform fault near its intersection with the crest of the East Pacific Rise (EPR). Whole-rock and electron probe analyses of fresh glass from pillow margins demonstrate that these are the most primitive basalts so far found in the eastern Pacific. $\mathrm{MgO}$ in the glass is 11.3 per cent. Variations in the compositions of the picrites result from accumulation of olivine $\left(\mathrm{Fo}_{89-86}\right)$ and spinelphenocrysts. Olivine spherulites are abundant near the glassy rims. Orthopyroxene (bronzite) and plagioclase crystallites and spherulites also grew near pillow margins. The phenocrysts enclose trapped glasses which are even more primitive than glass selvages. Fractionation of olivine and spinel would produce other less primitive olivine-bearing tholeiites found in the area, which in turn would give rise to the abundant ferrobasalts of the area by crystal fractionation. We thus propose that olivine-rich basalts with magnesian glasses such as our picrites are the probable parents of the entire eastern Pacific mid-ocean ridge tholeiite suite. The widespread occurrence of ferrobasalts and other fractionated basalts erupted from the axial summit of the EPR implies that they were tapped from shallow levels in the axial magma reservoir, whereas the picrites were tapped from deeper levels along crosscutting fracture-zone faults.
\end{abstract}

\section{INTRODUCTION}

During the Siqueiros Expedition (1974) of the Scripps Institution of Oceanography, a combined seismic refraction, gravity, and dredging program was conducted along the East Pacific Rise (EPR) and Siqueiros fracture zone transform fault. Most of the important results of this program have been discussed elsewhere (e.g., Batiza et al., 1977; Dorman, 1975; Orcutt et al., 1975; in press, Rosendahl, 1976; and Rosendahl et al., 1976) with one major exception, which pertains to a dredge haul of picritic basalts from the Siqueiros transform fault and fracture zone.

Apparently, picrite is a rare rock type on sea floor created at mid-ocean ridges, and only a few other instances are known to us (e.g., Bougault and Hekinian, 1974; DSDP Leg 37, Aumento, Melson, et al., 1977). Yet these rocks are not merely curiosities, for it has long been speculated that primitive picritic-type rocks could represent the melt compositions from which the ubiquitous ocean floor tholeiites are derived. In this paper we present the petrology and chemistry of the Siqueiros picrite and discuss its relevance to magmatic processes at trailing plate edges.

\footnotetext{
${ }^{1}$ Present address: Department of Geology/Geography, The University of Alabama, University, Alabama.
}

\section{BACKGROUND}

Previous work in the Siqueiros area has demonstrated that the EPR is underlain by a low-velocity zone which probably represents a shallow magma reservoir for tholeiitic liquids generated in the upper mantle (Rosendahl et al., 1976). As noted by Rosendahl (1976), the presence of such a reservoir complicates the identification of tholeiitic basalt parental composition, because significant fractionation and other modifications of melt chemistry (e.g., oxidation, incorporation of sea water, and magma mixing) could occur in the reservoir. In the Siqueiros area it appears that such imprints could be quite important, explaining among other things, the relatively evolved character of most of the lavas compared with Mid-Atlantic Ridge tholeiites which are typically more primitive in their chemistry ("primitive" is used here in its simplest and original sense, referring in general to rocks with high $\mathrm{Mg} /(\mathrm{Mg}+\mathrm{Fe})$, which are probable candidates for direct partial melts of the mantle; our picrites also have depleted LIL and related trace element abundances).

\section{LOCATION AND MACROSCOPIC DESCRIPTIONS}

The Siqueiros picrites recovered in dredge SD-7 $\left(8^{\circ} 22.5^{\prime} \mathrm{N}, 103^{\circ} 40.6^{\prime} \mathrm{W}, 3535-3474\right.$ corrected meters of water depth), were located within the presently active decoupling zone of the Siqueiros transform fault (Figure 1). In all probability the samples came from the low- 


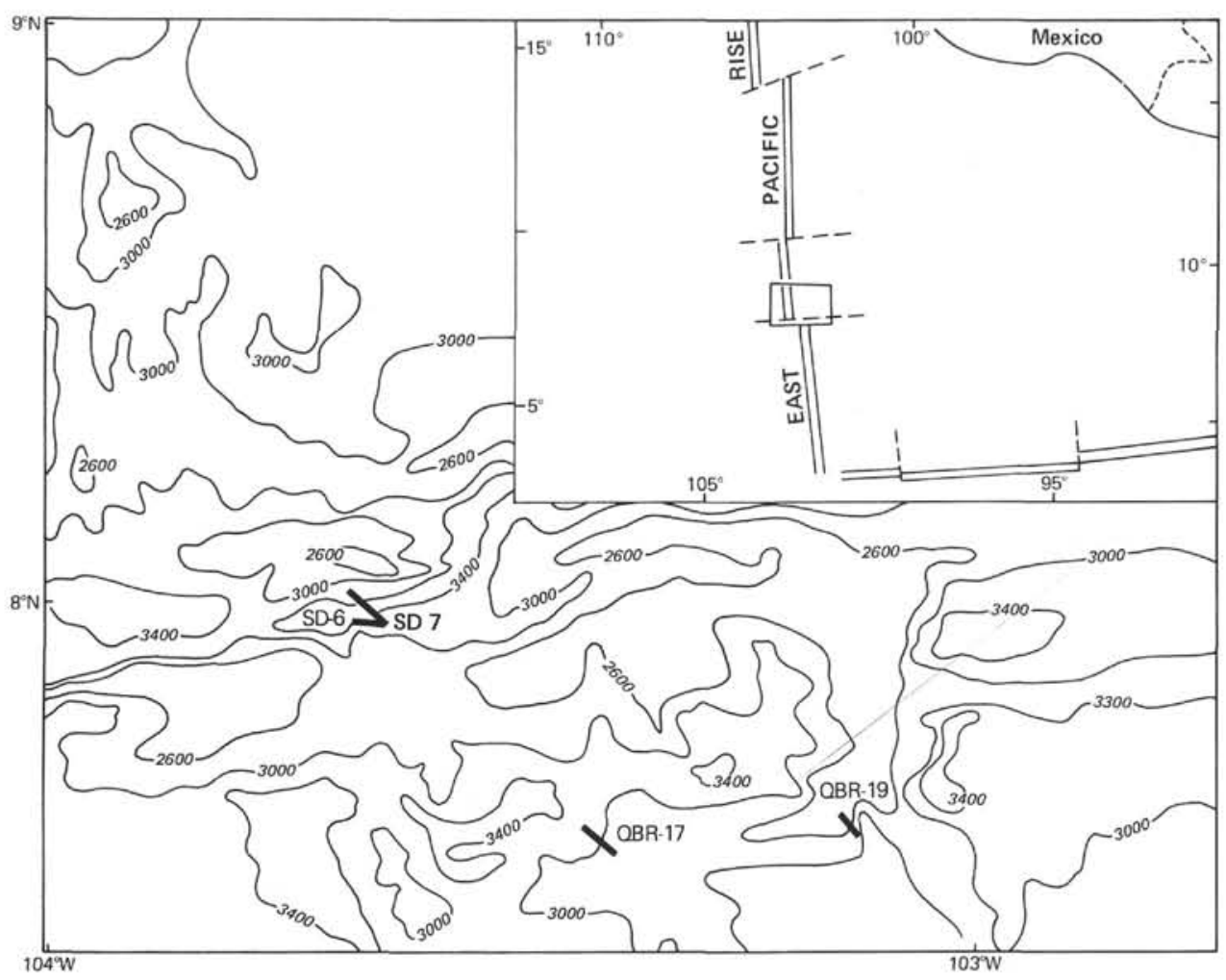

Figure 1. Location map of the dredge areas.

er flank of a small ridge that marks the transition between north-south lineated, crust to the north, and east-west trending transform fault structures to the south. The entire dredge-haul $(\sim 1000 \mathrm{~kg})$ consists of fresh picritic basalt, most of which appears to be blocky, "pie-shaped" pieces of pillows or curved slabs with glass selvages. Picritic basalts were not recovered in any of the other Siqueiros dredge hauls (see Batiza et al., 1977 and Batiza and Johnson, this volume) including one (SD-6) which was located very near to SD-7.

\section{PETROGRAPHY AND MINERALOGY}

Microscopically, the samples can be divided into three distinct groups on the basis of mineralogy and texture: (1) those containing olivine and spinel phenocrysts in a predominantly glassy matrix (SD-7A); (2) those containing olivine and spinel phenocrysts in a glass-microlite matrix (SD-7B); and (3) those containing olivine and plagioclase phenocrysts in a 50-50 spherulite-rich, glass-plagioclase matrix. Small orthopyroxene crystals (approximately $3 \mu \mathrm{m}$ long) also are present in the SD-7A samples but were not used as a basis for sample subdivision. All samples fall into petrographic groups (1) and (2) of Batiza et al., (1977). A condensation of the optical mineralogic data is presented in Table 1 , and brief descriptions of the major mineral components are provided in the following sections.

\section{Olivine}

Olivine microphenocrysts range in size from 0.05 to $>2 \mathrm{~mm}$ in diameter. The SD-7A and SD-7B olivines are mainly euhedral, whereas the phenocrysts in the SD-7C
TABLE 1

Petrographic Data from Representative Samples

\begin{tabular}{|c|c|c|c|c|}
\hline Sample Group & Mineral Phases & $\begin{array}{c}\text { Abundance } \\
(\%)\end{array}$ & Texture & Remarks \\
\hline SD-7A & $\begin{array}{l}\text { Olivine } \\
\text { Spinel } \\
\text { Orthopyroxene }\end{array}$ & $\begin{array}{r}25 \\
2 \\
<1\end{array}$ & $\begin{array}{c}\text { Hyalopilitic } \\
\text { to } \\
\text { Holohyaline }\end{array}$ & $\begin{array}{l}\text { All crystals are } \\
\text { euhedral. }\end{array}$ \\
\hline SD-7B & $\begin{array}{l}\text { Olivine } \\
\text { Spinel } \\
\text { Plagioclase }(5 \mu) \\
\text { Microlites }(<5 \mu)\end{array}$ & $\begin{array}{r}20 \\
1 \\
<<1 \\
3-6\end{array}$ & Hyalopilitic & $\begin{array}{l}\text { All olivines and } \\
\text { spinels are euhedral. } \\
\text { Plagioclase is very rare, } \\
\text { small, and skeletar- } \\
\text { rectilinear. One or two } \\
\text { equant plagioclase } \\
\text { phenocrysts. }\end{array}$ \\
\hline SD-7C & $\begin{array}{l}\text { Olivine } \\
\text { Spinel } \\
\text { Plagioclase } \\
\text { Clinopyroxene } \\
\text { Titanomagnetite }\end{array}$ & $\begin{array}{l}15 \\
<1 \\
15 \\
20 \\
1-3\end{array}$ & Intersertal & $\begin{array}{l}\text { Flow of rectilinear } \\
\text { plagioclase crystal } \\
\text { groups is evident } \\
\text { around larger, } \\
\text { rounded olivines. } \\
\text { Individual plagioclase } \\
\text { phenocrysts make up } \\
\text { about } 5 \text { per cent of } \\
\text { the rock and are } \\
\text { unzoned, with equant } \\
\text { to lath-like morphologies }\end{array}$ \\
\hline
\end{tabular}

group are rounded anhedral to subhedral crystals. Compositionally, the olivine ranges from $\mathrm{Fo}_{89}$ in SD-7A to $\mathrm{Fo}_{86}$ in SD-7C (Table 2). Olivine phenocrysts in the most primitive tholeiites from dredges SD-6 and SD-8 are $\mathrm{Fo}_{86}$ (Batiza et al., 1977). None of the olivine crystals is compositionally zoned, but many show large Carlsbad-type twins with wavy extinction. Some olivine, especially in the SD-7A group, is probably accumulative. Glass inclusions are common in the SD-7A and SD7B crystals but nearly absent in the olivines of SD-7C. Evidence for rapid quenching of actively growing crystal facies is exhibited by some of the smaller olivines. 
TABLE 2

Microprobe Major Mineral Analysis (wt. \%)

\begin{tabular}{|c|c|c|c|c|c|c|c|}
\hline & \multirow[b]{2}{*}{ SD-7A } & \multirow{2}{*}{$\frac{\text { Olivine }}{\text { SD-7B }}$} & \multirow[b]{2}{*}{ SD-7C } & \multicolumn{2}{|c|}{ Plagioclase } & \multirow{2}{*}{$\begin{array}{c}\begin{array}{c}\text { Ortho- } \\
\text { pyroxene }\end{array} \\
\text { SD-7A }\end{array}$} & \multirow{2}{*}{$\begin{array}{l}\begin{array}{c}\text { Titano- } \\
\text { magnetit }\end{array} \\
\text { SD-7C }\end{array}$} \\
\hline & & & & SD-7B & SD-7C & & \\
\hline $\mathrm{SiO}_{2}$ & 40.47 & 40.21 & 41.10 & 50.59 & 50.93 & 53.9 & 0.11 \\
\hline $\mathrm{TiO}_{2}$ & 0.12 & 0.19 & 0.18 & - & - & 0.08 & 17.50 \\
\hline $\mathrm{Al}_{2} \mathrm{O}_{3}$ & 0.0 & 0.14 & 0.0 & 30.29 & 30.63 & 1.66 & 2.84 \\
\hline $\mathrm{FeO}^{\mathrm{a}^{2}}$ & 9.41 & 9.64 & 10.42 & 0.58 & 0.49 & 8.69 & 78.90 \\
\hline $\mathrm{MnO}$ & 0.55 & 0.54 & 0.99 & - & - & 0.20 & 0.39 \\
\hline $\mathrm{MgO}$ & 48.67 & 48.61 & 47.09 & - & - & 31.88 & 0.90 \\
\hline $\mathrm{CaO}$ & 0.44 & 0.54 & 0.34 & 14.47 & 14.71 & 3.19 & 0.10 \\
\hline $\mathrm{Na}_{2} \mathrm{O}$ & 0.23 & 0.22 & 0.24 & 2.83 & 3.14 & - & - \\
\hline $\mathrm{K}_{2} \mathrm{O}$ & - & - & - & 0.10 & 0.10 & - & - \\
\hline $\mathrm{NiO}$ & 0.29 & 0.36 & 0.31 & - & - & 0.22 & - \\
\hline \multirow[t]{2}{*}{ Total } & 100.18 & 100.25 & 100.66 & 99.10 & 100.01 & 99.82 & 100.74 \\
\hline & Fo89 & Fo88 & Fo86 & $\mathrm{An}_{74}$ & $\mathrm{An}_{72}$ & $\mathrm{Ca}_{7} \mathrm{Mg}_{73} \mathrm{Fe}_{20}$ & \\
\hline
\end{tabular}

${ }^{\mathrm{a} A l l} \mathrm{Fe}$ calculated as $\mathrm{FeO}$.

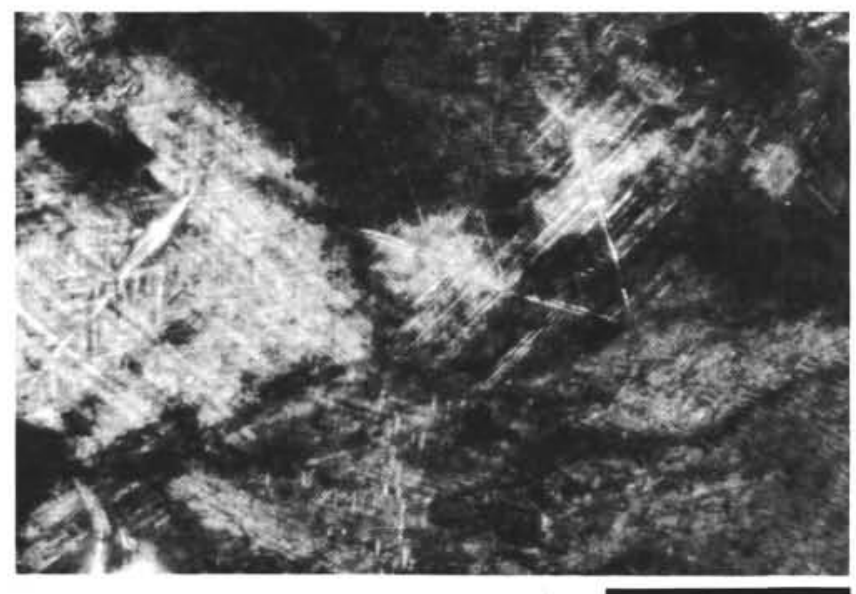

$60 \mu \mathrm{m}$

Figure 2. "Christmas Tree" quench pattern at junctures of olivine crystal faces from an SD-7B basalt. Scale $=15 \mu \mathrm{m}$.

For instance, swallowtail structures (Figure 2) can be present at the juncture of crystal faces that have had their growth halted by freezing of the nutrient melt. Near the glassy margin, these tiny olivine crystallites are abundant, each surrounded by a halo of reticulate and feathered secondary olivine fibers (Figures 2 and 3 ).

\section{Spinels}

Spinels are present in all of the samples examined and usually are included with glass in the larger olivines. However, they are most abundant in the SD-7A picrites. Although microprobe analyses were made difficult by abundant glass inclusions, the average spinel composition appears to be about 43 per cent $\mathrm{Al}_{2} \mathrm{O}_{3}, 20$ per cent $\mathrm{MgO}, 25$ per cent $\mathrm{Cr}_{2} \mathrm{O}_{3}$, and 12 per cent $\mathrm{FeO}^{2}$ (all expresed as wt. \%). These percentages remain relatively constant throughout the entire suite of samples.

\section{Plagioclase}

The plagioclase microphenocrysts are unzoned and range in composition from $\mathrm{An}_{72}$ to $\mathrm{An}_{74}$ (Table 2). They are predominantly skeletal to subequant laths twinned

\footnotetext{
${ }^{2}$ Expressing total iron.
}

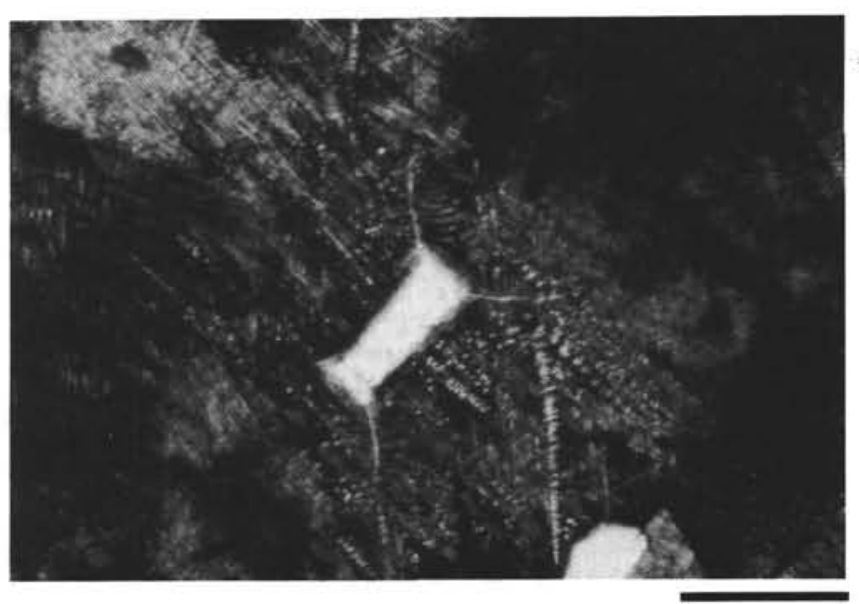

$15 \mu \mathrm{m}$

Figure 3. Reticulate olivine fibers and crystallites in glass matrix of $S D-7 B$ basalt. Scale $=25 \mu \mathrm{m}$.

on the Carlsbad law. A large size range ( 0.5 to $30 \mu \mathrm{m}$ in width) exists in the plagioclase crystals, both between and among the sample groups. Microlites in SD-7B are incipient plagioclase laths. Brown plagioclase spherulites occur near glassy rims; larger needles in such spherulites have grown to widths of approximately 5 $\mu \mathrm{m}$. One such crystal in the SD-7B sample group is $\mathrm{An}_{74}$ in composition (Table 2).

Where portions of the lava cooled more slowly, olivine and plagioclase spherulites intersected, and both olivine and plagioclase formed euhedral crystals (Figure 4). Some of the euhedral plagioclases grew in loose skeletal clusters and parallel arrays (Figure 4), perhaps because of heterogeneous nucleation. These fragments of crystal groups are similar to the megacrysts of Batiza et al. (1977) and Melson and Thompson (1971), but do not have sodic rims nor show evidence for resorption. Still, the glassy inclusions in the megacrysts do have associated gas bubbles as described by Batiza et al. (1977).

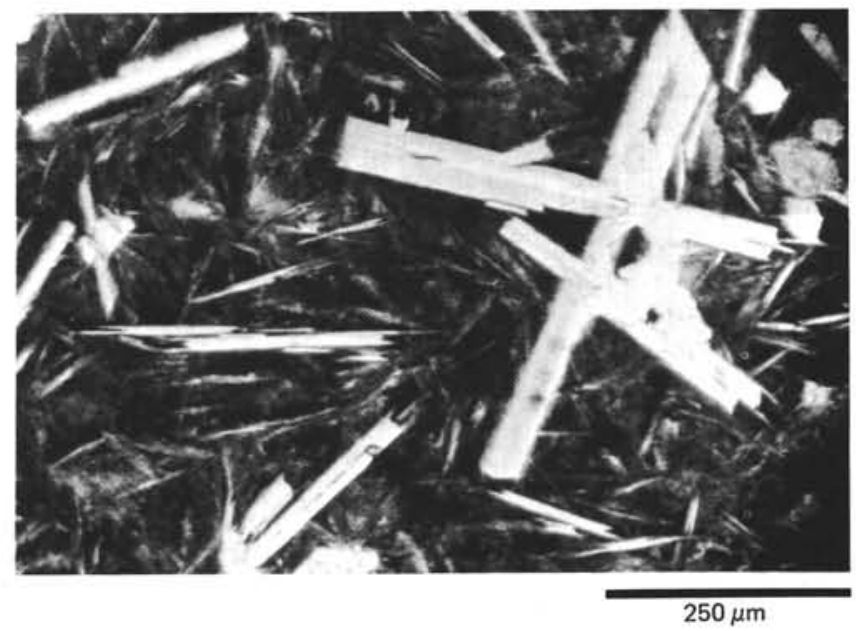

Figure 4. Euhedral and skeletal $A n_{72}$ laths in $S D-7 C$ basalt. Scale $=250 \mu \mathrm{m}$. 


\section{Orthopyroxene}

$\mathrm{Fe}-\mathrm{Mg}$ pyroxenes are found only in the SD-7A sample group and occur as small skeletal to euhedral crystals of bronzite ranging from $<1 \mu \mathrm{m}$ to $5 \mu \mathrm{m}$ in diameter (Tables 1 and 2). The crystals are untwinned, exhibit uniform parallel extinction, have dendritic projections, and served as nucleation sites for secondary fibrous growth (Figure 5). The fibers in such grains all show simultaneous extinction parallel to the long axis and are evidently also orthopyroxene. The latter thus was growing in these basalts upon extrusion. The bronzites from SD-7A are more Mg-rich than typical orthopyroxenes in many mafic volcanic and plutonic sequences (Ishii, 1975). They approach the enstatites reported from Icelandic flows by Sigurdsson and Brown (1969). These relationships are plotted in Figure 6.

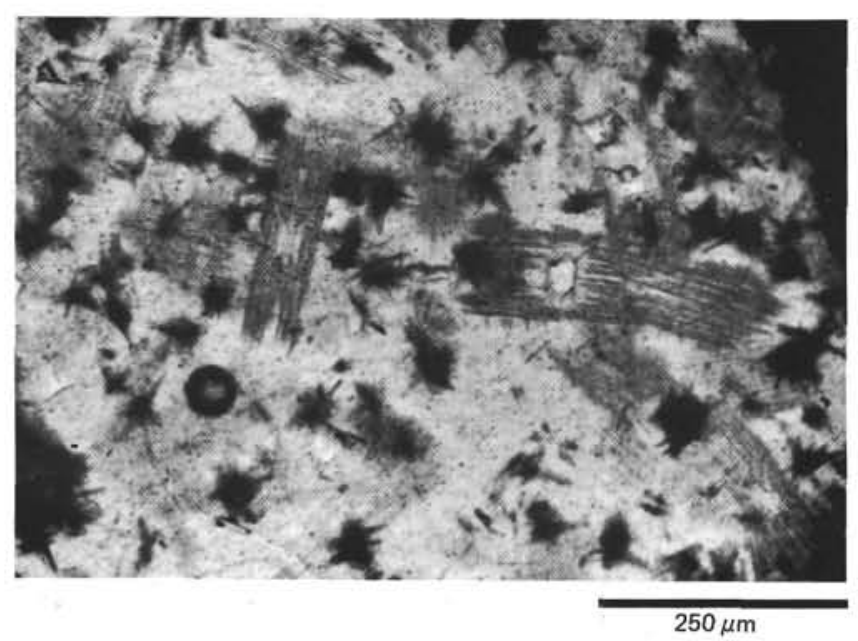

Figure 5. Orthopyroxene with dendritic projection and secondary fibers floating in glass matrix. Black, incipient plagioclase spherulites are also present. Scale $=60 \mu \mathrm{m}$.

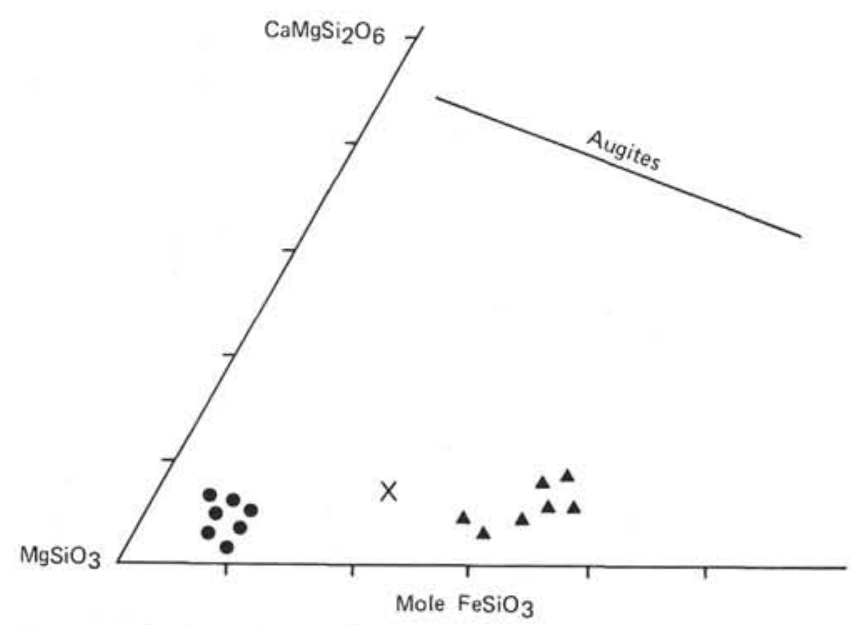

Figure 6. Portion of the pyroxene quadrilateral in which SD-7A orthopyroxene is plotted $(X)$. Triangles are volcanic bronzites (Ishii, 1975). Dots are volcanic enstatites from Iceland (Sigurdsson and Brown, 1969).

\section{Other Minerals}

Away from pillow margins between euhedral olivines and skeletal to euhedral plagioclases, there is a brown mesostasis consisting of very fine feathery dendritic brown clinopyroxene, powdery dusts of opaques, and brown glass. A few 2- to 4- $\mu \mathrm{m}$ titanomagnetites (Tables 1 and 2) have grown between some plagioclase laths, but do not comprise more than 3.5 per cent of any sample.

\section{MINERAL PARAGENESIS AND DEVELOPMENT OF ROCK TEXTURES}

The crystallization sequence of the major minerals can be established from textural relationships. Spinels crystallized first, as indicated by their inclusion in the euhedral and skeletal olivine crystals. Perhaps the spinels afforded nucleation sites for the olivines to crystallize. In the SD-7C samples, olivine and spinel are enclosed in a plagioclase lath matrix; hence, the plagioclase crystals must have formed after the olivines and spinels. Surrounding all these crystals are the tiny fibrous clinopyroxenes and dust-like titanomagnetites of the mesostasis. These were the last two minerals to form.

We cannot define from textural relationships when the bronzite began growing relative to the spinel-olivine sequence. It was almost certainly simultaneous with these minerals upon extrusion, but where it first began to crystallize is uncertain. Despite their tholeiitic chemistry, sea-floor basalts almost never have a crystallizing orthopyroxene mineral. Experimental data suggest that orthopyroxenes may crystallize from tholeiitic magmas similar to sea-floor basalts at temperatures between $1200^{\circ}$ and $1300^{\circ} \mathrm{C}$ and at pressures of $9 \mathrm{kbar}$ or higher (Kushiro, 1973; Green and Ringwood, 1967). Also, Macgregor (1974) reported Al-rich enstatites crystallizing in equilibrium with spinel and forsterite at $1300^{\circ} \mathrm{C}$ and 15 kbar. Presumably, then, all three minerals could have begun to crystallize at high pressures, although no definitive statement can be made about high-pressure mineral assemblages in these basalts until they are subjected to the same type of high-pressure experiments.

\section{CHEMICAL ANALYSES}

Both whole-rock chemical analyses (Table 3 ) and electron microprobe analyses of mineral phases and glasses (Tables 2 and 4) were performed on the samples. The whole-rock analyses, performed at Virginia Polytechnic Institution and State University, were obtained by X-ray fluorescence spectroscopy by calibration against USGS standards. Triplicate analyses were performed, and in no case did the averages of these analyses deviate by more than 8 per cent about the mean or 5 per cent from the standards. The reported electron microprobe analyses, performed at the University of Georgia, comprise an average of five analyses with less than 5 per cent variation about the mean. Trace element analyses were obtained by neutron activation from the Nuclear Engineering Laboratory at Virginia Polytechnic Institution and State University.

The whole-rock data and microprobe analyses of interstitial glasses lend credence to the statement of 
TABLE 3

Whole-Rock Chemical Analyses

\begin{tabular}{lrrr}
\hline \multicolumn{4}{c}{ Major Oxides in wt. \% (XRF) } \\
\cline { 2 - 4 } & SD-7A & \multicolumn{1}{c}{ SD-7B } & \multicolumn{1}{c}{ SD-7C } \\
\hline $\mathrm{SiO}_{2}$ & 48.19 & 47.78 & 47.74 \\
$\mathrm{TiO}_{2}$ & 0.83 & 0.86 & 1.68 \\
$\mathrm{Al}_{2} \mathrm{O}_{3}$ & 14.12 & 14.50 & 14.83 \\
$\mathrm{Fe}_{2} \mathrm{O}_{3}$ & 0.95 & 0.93 & 1.07 \\
$\mathrm{FeO}$ & 8.37 & 8.24 & 9.46 \\
$\mathrm{MnO}$ & 0.14 & 0.14 & 0.16 \\
$\mathrm{MgO}$ & 15.23 & 13.27 & 11.29 \\
$\mathrm{CaO}$ & 10.19 & 10.64 & 12.13 \\
$\mathrm{Na} 2$ & 1.41 & 2.19 & 2.06 \\
$\mathrm{~K}_{2} \mathrm{O}$ & 0.02 & 0.06 & 0.14 \\
$\mathrm{P}_{2} \mathrm{O}_{5}$ & 0.14 & 0.13 & 0.15 \\
$\mathrm{LOI}\left(\mathrm{H}_{2} \mathrm{O}\right)$ & 0.41 & 0.26 & 0.16
\end{tabular}

Trace Elements in ppm (Neutron Activation)

\begin{tabular}{lrrc}
$\mathrm{Co}$ & 94.0 & 68.0 & 57.0 \\
$\mathrm{Cu}$ & 130.0 & 182.0 & 164.0 \\
$\mathrm{Cr}$ & 930.0 & 870.0 & 620.0 \\
$\mathrm{Ni}$ & 245.0 & 195.0 & 190.0 \\
$\mathrm{~Pb}$ & 2.0 & 1.7 & 1.81 \\
$\mathrm{Sr}$ & 140.0 & 125.0 & 132.0 \\
$\mathrm{~V}$ & 120.0 & 185.0 & 220.0 \\
$\mathrm{Eu}$ & 0.8 & 1.0 & 1.1 \\
$\mathrm{La}$ & 1.4 & 1.6 & 1.9 \\
$\mathrm{Lu}$ & 0.35 & 0.41 & 0.50 \\
\hline
\end{tabular}

TABLE 4

Microprobe Analyses of SD-7 Glass (wt. \%)

\begin{tabular}{lccr}
\hline & $\begin{array}{c}\text { Glass Included } \\
\text { in Spinels (SG) }\end{array}$ & $\begin{array}{c}\text { Glass Included } \\
\text { in Olivines (OG) }\end{array}$ & $\begin{array}{c}\text { Matrix } \\
\text { Glass (MG) }\end{array}$ \\
\hline $\mathrm{SiO}_{2}$ & 46.55 & 49.96 & 50.93 \\
$\mathrm{TiO}_{2}$ & 0.76 & 0.87 & 1.01 \\
$\mathrm{Al}_{2} \mathrm{O}_{3}$ & 17.96 & 19.44 & 17.27 \\
$\mathrm{FeO}$ & 6.93 & 7.43 & 7.67 \\
$\mathrm{MnO}$ & 0.24 & 0.15 & 0.20 \\
$\mathrm{MgO}$ & 12.40 & 6.70 & 11.03 \\
$\mathrm{Cr}_{2} \mathrm{O}_{3}$ & 0.49 & 0.28 & 0.25 \\
$\mathrm{CaO}^{\mathrm{Na}}$ & 14.14 & 14.96 & 11.36 \\
$\mathrm{NiO}$ & 0.10 & 0.27 & 0.36 \\
& 0.13 & 0.04 & 0.06 \\
$\mathrm{Totals}$ & 99.7 & 100.1 & 100.22 \\
\hline
\end{tabular}

Batiza et al. (1977) that the SD-7 samples are the most primitive rocks yet obtained from this part of the eastern Pacific. Also, the criteria described by Kay et al. (1970) and Frey et al.(1974) for primitive oceanic tholeiites are easily satisfied by the chemistry of the SD-7 samples. For example, in all samples the $\mathrm{MgO}$ weight percentages exceed 9.0, and the Ni contents vary between 190 and $245 \mathrm{ppm}$.

Comparison of SD-7 whole-rock chemistries with those from other dredged samples of tholeiite in the Siqueiros area (particularly SD-6) shows a relative enrichment in $\mathrm{MgO}, \mathrm{Ni}$, and $\mathrm{Cr}$, and depletion in $\mathrm{FeO}^{*}, \mathrm{~V}$, $\mathrm{Na}_{2} \mathrm{O}, \mathrm{P}_{2} \mathrm{O}_{5}$, and $\mathrm{K}_{2} \mathrm{O}$, more or less along the extrapolations of the fractionation trends observed in dredge SD-6 (Figure 7a and $b$ ). These trends also follow those reported by Kay et al. (1970), Melson et al., (1968),
Shibata and Fox (1975), and Wright (1974) for oceanic tholeiites. Significantly, most of the fractionation trends seen in dredge SD- 6 can be produced or at least approximated by simple subtraction of $\mathrm{MgO}$, in the form of olivine, from SD-7 picrites. In fact, the SD-7A sample group appears to have an average composition that is quite close to the primitive basalt melt from which Batiza et al., (1977) calculated subtraction of 5 weight per cent of $\mathrm{FO}_{90}$ to match the relatively unfractionated compositions of dredges SD-6 and SD-8 tholeiitic samples. Two oxides, $\mathrm{Al}_{2} \mathrm{O}_{3}$ and $\mathrm{CaO}$, do not follow the SD-6 fractionation trends, but rather show gradual enrichment with decreasing $\mathrm{MgO}$ content (Figure 7a). This represents a reversal in the SD- 6 trends and is probably caused by the transition from an olivinecontrolled crystallization sequence in our samples to a plagioclase-clinopyroxene-olivine control in the SD-6 samples. Figure 7 clearly suggests that the picrite groups $(\mathrm{A}, \mathrm{B}$, and $\mathrm{C})$ represent three different stages of fractionation, with SD-7A being the least evolved.

Within the SD-7A group, there are three types of glass: (1) glass trapped in spinels, which were among the first minerals to crystallize (cf., Batiza et al., 1977; Yoder, 1976); (2) glass trapped in olivines; and (3) matrix glass. Because these glass stages offer a unique opportunity to monitor the early evolution of a chemically primitive tholeiitic liquid, we analyzed each using an electron microprobe (Table 4). The spinel-included glass, SG, is poorest in silica, whereas the olivine-included glass, OG, and matrix glass, MG, are progressively more silica-rich. This sequence appears to be directly related to progressive $\mathrm{SiO}_{2}$ enrichment in the fractionating magma. $\mathrm{Al}_{2} \mathrm{O}_{3}, \mathrm{FeO}^{*}$, and $\mathrm{MgO}$ concentrations vary according to the host minerals and their ability to buffer the included glass by preferentially incorporating or excluding certain elements from its structure. Thus, $\mathrm{Al}_{2} \mathrm{O}_{3}$ is on the one hand depleted in the glass trapped in the A1-rich spinel, and on the other hand enriched in the olivine-trapped glass. The crystallization of plagioclase may again deplete melts in $\mathrm{Al}_{2} \mathrm{O}_{3}$, which is reflected in the composition of the matrix glass. Similarly, $\mathrm{MgO}$ is depleted in the melt from which olivine is crystallizing, and $\mathrm{FeO}$ is lower in the glass included in the high-Fe spinel phase. $\mathrm{CaO}$ is relatively constant in the first two glasses (e.g., SG and OG), but is depleted in the pillow-rim glass. This follows $\mathrm{Al}_{2} \mathrm{O}_{3}$, thus apparently reflecting the late appearance of plagioclase. The $\mathrm{Ni}, \mathrm{Cr}$, and $\mathrm{Ti}$ trends reflect the general differentiation indices suggested by Wright (1974). Both $\mathrm{Ni}$ and $\mathrm{Cr}$ decrease as $\mathrm{Ti}$ apparently becomes enriched in the melt. $\mathrm{MgO}$ in the selvage glass is nevertheless higher than in any other whole-rock analysis from the Siqueiros region; hence, it makes these picrites as close to potential direct mantle, partial melts as have ever been obtained from the eastern Pacific ocean floor. The selvage glass is similar to the most primitive Mid-Atlantic Ridge glass reported by Frey et al. (1974).

In general, the chemical changes in magmatic compositions, from initial oxide crystallization to final quenching on the ocean floor, can be followed with these glass data. SG represents a relatively unfraction- 

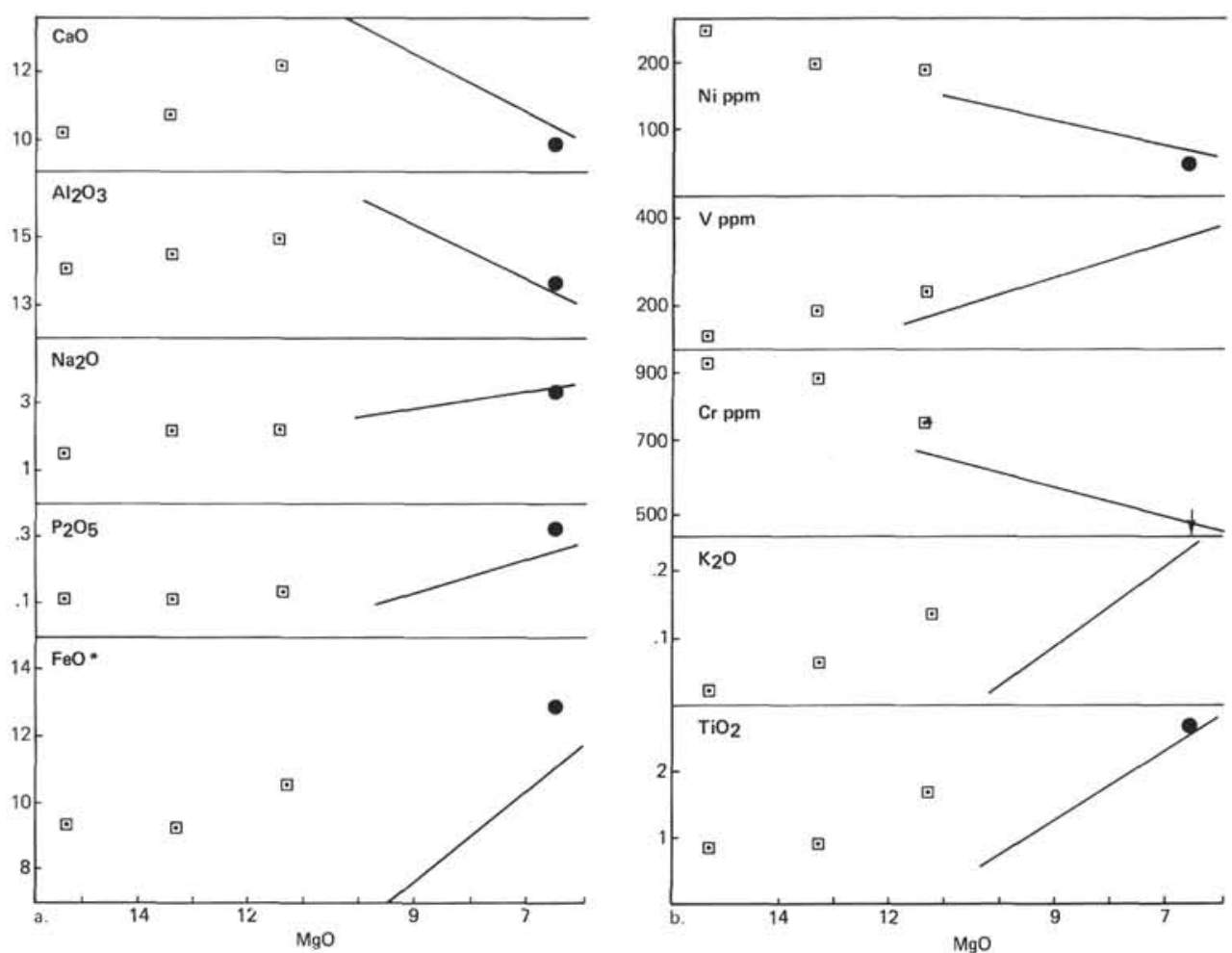

Figure 7. ( $a$ and b) $\mathrm{MgO}$ variation diagrams relating Siqueiros picrites (squares enclosing solid dots), approximate SD-6 fractionation trends (Batiza et al., 1977), and representative analyses from DSDP Site.427 (large solid dot). Note: the Cr value for Site 427 plots below the diagram base and is so indicated by an arrow.

ated melt somewhat similar in composition to the SD7A group, while the MG composition more closely approximates the fine-grained tholeiites described by Engel and Engel (1964). Rather than comparing hypothesized fractionation sequences between different samples, we are able to monitor the same trends within one rock and thus see actual changes in one melt.

\section{DISCUSSION AND CONCLUSIONS}

\section{Source Relations}

The mineralogical, textural, and chemical characteristics of the SD-7A picrite imply that this rock originates somewhere below the crest of the axial magma chamber. Further precision cannot be achieved because the SD-7A sample group contains no phenocrystal clinopyroxene, but only bronzite, which has a $\mathrm{CaO}$ content of about 3.2 weight per cent. Hence, neither the orthopyroxene-clinopyroxene geobarometer of Presnell (1976) nor the orthoenstatite geobarometer of Macgregor (1974) are applicable.

The SD-7B and 7C sample groups obviously have undergone progressively more crystal fractionation than the SD-7A samples, but it appears all three groups originated from the same parental material. In addition to their spatial coincidence, there is a relative increase in $\mathrm{Fe}, \mathrm{N}, \mathrm{K}, \mathrm{Mn}, \mathrm{Sr}, \mathrm{Cu}, \mathrm{Hf}, \mathrm{Ti}$, and $\mathrm{Si}$ and a decrease in $\mathrm{Mg}, \mathrm{Co}, \mathrm{Cr}, \mathrm{Ni}$, and $\mathrm{Rb}$ from the SD-7A to $7 \mathrm{C}$ groups. These trends have been cited by Kay et al. (1970), Frey et al. (1974), and Wright (1974) as differentiation in- dices for genetically related magmas. A common parental source also is suggested by the spinel compositions, which are fairly consistent in all three sample groups. The three rare-earth elements we have obtained show light-rare-earth depleted values (Figure 8), with La between four and six times chondritic values, comparable to values in the most primitive South Atlantic basalts reported in Frey et al. (1974).

The source relations between SD-7 samples and the tholeiites recovered in the other Siqueiros dredges are

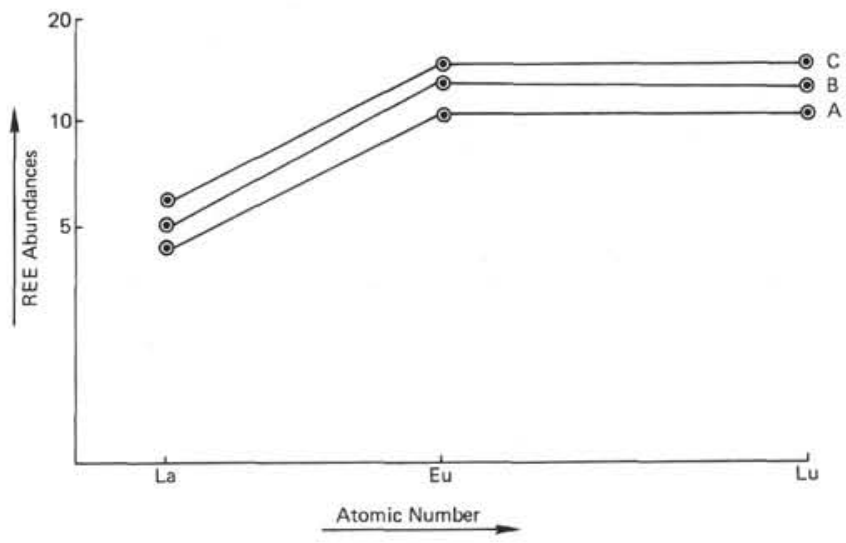

Figure 8. The log of chondrite-normalized rare earth abundances plotted against atomic number of three rare-earth elements. 
more difficult to establish than those for the SD-7 groups themselves. However, the fact that the unfractionated SD- 6 and SD- 8 tholeiites can be produced from an SD-7A liquid by crystal fractionation of first olivine and then plagioclase strongly suggests at least a similarity of source.

Therefore, it would appear that the primary differences both within the SD-7 sample groups and between these groups and the tholeiitic basalts recovered in the other Siqueiros dredge hauls are principally a result of variations in the degree and depth of fractionation of a genetically similar melt. We believe the axial magma reservoir thought to underlie the EPR plays a leading role in the production of these variations, as outlined in the following hypothesis.

\section{Tholeiitic Magma Evolution}

We postulate that partial melting of the mantle below the Siqueiros transform fault produces a tholeiitic liquid with a chemistry only slightly more primitive than that of the SD-7A sample group (Table 3). This liquid is apparently removed from the source region soon after the onset of melting and may undergo minor crystal fractionation during its ascent into a shallow magma reservoir.

Once injected into the reservoir, each batch of tholeiitic liquid will tend to rise toward the top of the reservoir (Sleep, 1976) and become concentrated in what Rosendahl (1976) envisions as a mushroom-shaped cap. Because of gravity differentiation/segregation, mafic mineral phases and possible cumulate ores would, of course, become preferentially concentrated in the basal portion of the reservoir, perhaps in the form of a crystal-liquid mush (Sleep, in press). If the reservoir is tapped near its top (e.g., at a sub-basement depth of 2 to $3 \mathrm{~km}$ ), we would expect an eruption of moderately fractionated tholeiite in which plagioclase and clinopyroxene are coprecipitating and from which olivine or olivine and plagioclase previously have been precipitated. The moderately to highly fractionated tholeiites of Batiza et al. (1977) are thought to represent such a case. Tapping deeper levels of the reservoir should produce liquids that are relatively primitive in chemistry and enriched in early-formed mafic phenocryst phases, such as olivine, spinel, and orthopyroxenes.

Although surely overly simplistic, this theory is consistent with the known petrographic and chemical data from the Siqueiros region and has the decided advantage of interlinking petrologic and geophysical constraints. Another asset of this hypothesis arises from its predictive powers in terms of spatial relations and relative volumes of tholeiitic lava type. As outlined by Rosendahl (1976), the loci of dike injection and eruption along the EPR would be determined by the stress field in the rocks overlying the magma reservoir. The work of Fiske and Jackson (1972) demonstrates that this stress field is conducive to preferential injection and eruption along the topographic axis of the EPR. Furthermore, a consideration of stress trajectories requires that most eruptive events originate from the apex or cap region of the reservoir (i.e., the high-angle fracture patterns in the material above the reservoir tend to converge on the reservoir's summit viewed in cross section). Therefore, assuming steady-state conditions (the geomorphology of the EPR axial block is maintained as spreading continues) and two-dimensionality, we would predict a prevalence of moderately to highly fractionated tholeiite in EPR axial eruptions. The existing data appear to support this prediction (e.g., Batiza et al., 1977; Rosendahl, 1976). Near or at the junctions of transform faults and ridge crests, the two-dimensionality assumption breaks down and one must then also consider stress trajectories in the vertical planes that are not just perpendicular to the EPR axis. The problem is very complex, but two important relationships become evident: 1) The trajectories of the maximum stress viewed in the axial plane of the EPR theoretically would intersect progressively deeper levels of the magma reservoir, as one proceeds across the transform fault (cf., Rea, 1975); and 2) The period between eruptive events at a given place would increase in the same direction. Hence, we could surmise that eruptions originating from the axial magma reservoir but occurring in, say, the Siqueiros transform fault would be chemically more primitive and less frequent than those at the EPR axis. The fact that most of the unfractionated tholeiites in the study by Batiza et al. (1977) and the picrites discussed therein, are found in the Siqueiros fracture zone and transform fault, and that these constitute considerable depressions of the regional sea-floor depth (i.e., not flooded with basalt), supports this supposition.

A related problem with the simple hypothesis outlined above is that all major differentiation is presumed to occur in the reservoir, when in fact Wright and Fiske (1971) have demonstrated that differentiation can be significant in the dike zones beneath the Hawaiian rift. Hence, it seems likely that some variations in the degree of fractionation in tholeiites occur after the magma leaves the reservoir. The geomorphology of the rise crest in this vicinity strongly support the notion that dikes feed axial eruptions (Lonsdale and Spiess, this volume). But it is also likely that a dike swarm of molten material at the top of the reservoir would be detectable as part of the axial velocity inversion (Rosendahl, et al., 1976), using explosion seismology technology techniques, and hence would be indistinguishable from any more coherent magma chamber. Therefore, we lack the criteria upon which to evaluate the relative importance of differentiation in a crestal magma chamber with respect to that in superjacent dike zones; probably, both contribute.

\section{ACKNOWLEDGMENTS}

The authors appreciate the discussion and suggestions offered by the Scientific Party of DSDP Leg 54 on the Glomar Challenger. We also gratefully acknowledge shipboard chemical analyses performed on Leg 54 by Louis Briqueu. Special thanks to Drs. Ron Fodor, Susan Humphris, and James Natland for critical reading of drafts of this manuscript. Data processing time and techniques were contributed by William Size of Emory University, and duplicate whole-rock analyses were provided by Mike Higgins of the U.S. Geological Survey. 


\section{REFERENCES}

Aumento, F., Melson, W. G., et al., 1977. Initial Reports of the Deep Sea Drilling Project, v. 37: Washington (U.S. Government Printing Office).

Batiza, R., Rosendahl, B. R., and Fisher, R. L., 1977. Evolution of oceanic crust 3. Petrology and chemistry of basalts from the East Pacific Rise and Siqueiros transform fault. $J$. Geophys. Res.,v. 82, p. 265-276.

Bence, A. E., Papike, J. J., and Ayuso, R. A., 1975. Petrology of submarine basalts from the central Caribbean: DSDP Leg 15. Ibid., v. 80, p. 4775-4804.

Bougault, H., and Hekinian, R., 1974. Rift valley in the Atlantic Ocean near $36^{\circ} 50^{\prime} \mathrm{N}$ : Petrology and geochemistry of basaltic rocks. Earth Planet. Sci. Lett., v. 24, p. 249-261.

Bryan, W. B., 1974. Fe-Mg relationships in sector-zoned submarine basalt plagioclase. Ibid., p. 157-165.

Dorman, L. M., 1975. The isostatic compensation of the topography at the crest of the East Pacific Rise. Trans. Am. Geophys. Union, v. 56, p. 1064.

Engel, A. E. J., and Engel, C. G., 1964. Igneous rocks of the East Pacific Rise. Science, v. 146, p. 477-485.

Fiske, R. L., and Jackson, E. D., 1972. Orientation and growth of Hawaiian volcanic rifts: The effect of regional structure and gravitational stresses. Proc. Roy. Soc. London, v. 329, p. 299.

Frey, F. A., Bryan, W. B., and Thompson, G., 1974. Geochemistry and petrology of basalts from Legs 2 and 3 of the Deep-Sea Drilling Project. J. Geophys. Res., v. 79, p. 5507-5527.

Green, D. H., and Ringwood, A. E., 1967. The genesis of basalt magmas. Contrib. Mineral. Petrol., v. 15, p. 103-190.

Kay, R. N., Hubbard, N., and Gast, P. W., 1970. Chemical characteristics of oceanic ridge volcanic rocks. J. Geophys. Res., v. 75, p. 1585-1613.

Kushiro, I., 1973. Crystallization of pyroxenes in Apollo 15 mare basalts. Carnegie Institution of Washington Year Book, v. 72, p. 647-650.

Macgregor, I. D., 1974. The system $\mathrm{MgO}-\mathrm{Al}_{2} \mathrm{O}_{3}-\mathrm{SiO}_{2}$ : Solubility of $\mathrm{Al}_{2} \mathrm{O}_{3}$ in enstatite for spinel and garnet peridotite compositions. Am. Mineral., v. 59, p. 110-119.
Melson, W. G., and Thompson, G., 1971. Petrology of a transform fault and adjacent ridge segments. Phil. Trans. Roy. Soc. London, Ser. A, v. 268, p. 423-441.

Melson, W. G. M., Thompson, G., and van Andel, Tj. H., 1968. Volcanism and metamorphism in the Mid-Atlantic Ridge, $22^{\circ} \mathrm{N}$ latitude. J. Geophys. Res., v. 74, p. 59255942.

Orcutt, J. A., Kennett, B. L. N., and Dorman, L. M., in press. Structure of the East Pacific Rise from an ocean bottom seismometer survey. Geophys. J. Roy. Astron. Soc.

Orcutt, J. A., Kennett, B. L. N., Dorman, L. M., and Prothero, W. A., 1975. Evidence for a low-velocity zone underlying a fast-spreading rise crest. Nature, v. 256, p. 475.

Presnell, D. C., 1976. Alumina content of enstatite as a geobarometer for plagioclase and spinel therzolites. Am. Mineral., v. 61 , p. 582-588.

Rea, D. K., 1975. Model for the formation of topographic features of the East Pacific Rise crest. Geology, v. 3, p. 77.

Rosendahl, B. R., 1976. Evolution of oceanic crust. 2. Constraints, implications, and inferences. J. Geophys. Res., v. 81, p. $5305-5314$.

Rosendahl, B. R., Raitt, R. W., Dorman, L. M., and Bibee, L. D., 1976. Evolution of oceanic crust. 1. A physical model of the East Pacific Rise crest derived from seismic refraction data. Ibid., p. 5294-5304.

Shibata, T., and Fox, P. J., 1975. Fractionation of abyssal tholeiites: Samples from the Oceanographer fracture zone $\left(35^{\circ} \mathrm{N}, 35^{\circ} \mathrm{W}\right)$. Earth Planet. Sci. Lett., v. 27 , p. 62-72.

Sleep, N. H., in press. Topography and tectonics of ridge axis. J. Geophys. Res.

Wright, T. L., 1974. Presentation and interpretation of chemical data for igneous rocks. Contrib. Mineral. Petrol., v. 48 , p. $233-247$.

Wright, T. L., and Fiske, R. S., 1971. Origin of the differential and hybrid lavas of Kilauea volcano, Hawaii. $J$. Petrol., v. 12, p. 1.

Yoder, H. S., 1976. Generation of Basaltic Magma: Washington (National Academy of Sciences). 